\title{
Preparation, Characterization and Evaluation of Nano Zinc Oxides as Pigments
}

\author{
A. A. Hanna, W. A. A. Mohamed and Hoda R. Galal \\ Inorganic Chemistry Department, National Research Center, \\ Giza, Egypt.
}

\begin{abstract}
TR HREE samples of nano zinc oxide are prepared by using both the hydrothermal and the direct precipitation methods. The characterization of the produced samples shows that the prepared samples have different nano size. Also, it is found that there are an agreement between the calculated values of the particle size from the $\mathrm{x}$-ray diffraction and the TEM measurements. On other hand, the prepared samples are tested as pigments according to the ASTM (1980 and 1981) for comparison with a commercial $\mathrm{ZnO}$. The test showed that the nano sized $\mathrm{ZnO}$ exhibits an excellent property when used as pigments relative to the commercial sample.
\end{abstract}

Keywords: Nano zinc oxide, Hydrothermal, Precipitation and Pigment .

Zinc oxide $(\mathrm{ZnO})$ powders have different applications. For example as catalysts, in paints and other construction applications (1) .By introducing the nano technology, zinc oxide gains a special attention. Zinc oxide nano sized powder have unique optical and electrical properties ${ }^{(1-3)}$, which introduce advanced applications such as chemical and gas sensors, rubber industry to reduce vulcanization process time, cosmetic and pharmaceutical industries ${ }^{(4-6)}$. Thin films of nano sized $\mathrm{ZnO}$ are used in the more advanced applications such as transparent transistors ${ }^{(7)}$, solar and photovoltaic devices ${ }^{(8,9)}$, UV rays, and varistors $^{(10,11)}$.

In general, zinc oxide powder is produced by three distinct processes ${ }^{(4,12)}$; direct oxidizing zinc metal, or reduction of an ore to zinc metal followed by controlled re-oxidation, to a far lesser extent or precipitation of the oxide or carbonate from an aqueous solution followed by calcinations. Where Nano-sized zinc oxides are prepared by using different advanced methods such as, sol-gel method ${ }^{(5,13)}$, thermal deposition, spray pyrolysis and modified precipitation methods.

Chang Chun Chen et al. used the direct precipitation method to synthesize nano-sized $\mathrm{ZnO}$ particles using some alternative raw materials to study their effects on the macrostructure of the product ${ }^{(1)}$. Chou et al. prepared nano-sized zinc oxide from $\mathrm{Zn}\left(\mathrm{NO}_{3}\right)_{2}$ solutions containing hexamethylene tetra amine. They found that the shape of the obtained particles depend on the $\mathrm{pH}$ of the medium of the reactions ${ }^{(14)}$. The micro emulsion method was also used to prepare Zno nano sized particles by Singhal et al. ${ }^{(15)}$. Komaraeni et al. ${ }^{(16)}$ used micro wave 
irradiation of $\mathrm{Zn}\left(\mathrm{NO}_{3}\right)_{2}$ solutions neutralized at $\mathrm{pH}$ 8-12 to prepare $\mathrm{ZnO}$ nanparticles. T. Tsuchida and S. Kitajima ${ }^{(17)}$ applied mechano-chemical processing in the synthesis of $\mathrm{ZnO}$, nanoparticles. The literature survey ${ }^{(1,14-17)}$ showed that chemical, physical and microstructure of $\mathrm{ZnO}$ powders are dependent on the synthesis procedure.

The aim of present work is preparation and characterization of $\mathrm{ZnO}$ nanosized various methods and studying the effect of temperature on the produced products. Also, this work extended to evaluate the produced materials as pigments according to the standard methods and in comparison with a commercial $\mathrm{ZnO}$.

\section{Materials and Methods}

\section{Materials}

Zinc 2-ethylhexanoate, $\mathrm{Zn}\left(\mathrm{CH}_{3} \mathrm{COO}\right)_{2} \cdot 2 \mathrm{H}_{2} \mathrm{O}$, containing $1 \%$ of ethylene glycomonomethylether supplied by Fluka. Tetra-methylaminehydroxide, TMAH, [(CH3)4NOH, 25\%, w/w aqueous solution, electronic grade, $99.99 \%$ supplied by Fluka. $\mathrm{Zn}\left(\mathrm{NO}_{3}\right)_{2}$ and $\left(\mathrm{NH}_{4}\right)_{2} \mathrm{CO}_{3}$ supplied from BDH. Absolute ethanol, 2propanol and $\mathrm{NH}_{4} \mathrm{OH}$ solution supplied by Kemika were used. All materials were used without further purification.

\section{Preparation methods of nano zinc oxide samples}

Three methods were used to prepare zinc oxide under different conditions. The first method is the hydrothermal treatment for the precurcer materials at short ageing. In this method $(1.00 \mathrm{~g})$ zinc 2-ethylhexanoate was mixed with $90 \mathrm{ml}$ of 2-propanol with continuous stirring. After stirring for $40 \mathrm{~min}$ a clear solution was appeared. Then, $10 \mathrm{ml}$ of $25 \%$ TMAH was added to the pervious solution with vigorous stirring. After this step the solution converted to the colloidal state. The colloidal solution was aged for $12 \mathrm{hr}$, washed carefully with ethanol and bidistilled water. Then a precipitation at room temperature was occurred. The formed precipitate was separated by using vigorous centrifuging and dried at $60{ }^{\circ} \mathrm{C}$, followed by autoclaving at $170^{\circ} \mathrm{C}$ for $12 \mathrm{hr}$ (sample I).

Sample II was prepared by adding $7 \mathrm{ml}$ of $\mathrm{H}_{2} \mathrm{O}$ to $100 \mathrm{ml}$ of $0.2 \mathrm{M}$ $\mathrm{Zn}\left(\mathrm{CH}_{3} \mathrm{COO}\right)_{2}$ solution. To this solution $3 \mathrm{ml}$ of concentrated $\mathrm{NH}_{4} \mathrm{OH}$ solution was added with vigorous stirring for $30 \mathrm{~min}$. The formed suspension was aged at room temperature for $72 \mathrm{hr}$. The solid precipitate was separated from the mother liquor by vigorous centrifuging. The isolated powder was washed with alcohol and bi-distilled water several times and dried at $60{ }^{\circ} \mathrm{C}$. Further treatment was carried by autoclaving at $160^{\circ} \mathrm{C}$ for $72 \mathrm{hr}$.

For the sample (III) the direct precipitation method was followed. In this method, firstly $\mathrm{Zn}\left(\mathrm{NO}_{3}\right)_{2}$ and $\left(\mathrm{NH}_{4}\right)_{2} \mathrm{CO}_{3}$ were prepared as a stock materials having 1.5 and $2.25 \mathrm{~mol} / \mathrm{L}$ concentration, respectively. The second step, $\mathrm{Zn}\left(\mathrm{NO}_{3}\right)_{2}$ solutions were slowly dropped into the $\left(\mathrm{NH}_{4}\right)_{2} \mathrm{CO}_{3}$ solutions with the

Egypt. J. Chem. 57, No. 5,6 (2014) 
vigorously stirring. The product of the reaction between the two start solutions were separated by filtration and washed with bi-distilled water and ethanol, respectively. The produced powder was dried at $80{ }^{\circ} \mathrm{C}$ followed by calcination at $550 \circ \mathrm{C}$ for $2 \mathrm{hr}$.

\section{Characterization of zinc oxide samples}

The dried produced samples were characterized by using X-ray diffraction. The morphology was examined using transmission electron microscope TEM. The X-ray diffraction, was performed by Philips diffractometer, (type P.W. 1390) using Ni-filtered $\mathrm{Cu} \mathrm{K} \alpha$ radiation $(\lambda=1.5405 \AA)$. The $\mathrm{X}$-ray tube was operated at $36 \mathrm{kV}$ and $16 \mathrm{~mA}$. The diffraction angle $2 \theta$ was scanned at a rate of $2^{\circ} \min ^{-1}$. For the TEM measurements, the tested samples were prepared by dispersing distilled water followed by ultrasonic vibration for half an hour. Then, a drop of the dispersed sample was placed onto a copper grid coated with a layer of amorphous carbon. A Jeol Transmission Electron Microscope, Jel 1230, RV $120 \mathrm{KV}$ was used.

\section{Evaluation of zinc oxide samples as pigments}

The main measurements for evaluation of the produced samples as pigments were carried out according to the ASTM D (1980) and ASTM D (1981). In this evaluation, the specefic gravity, oil adsorption, hiding power, performance to heat and chemical resistance (acid and alkali resistances) were performed for the samples.

\section{Results and Discussion}

\section{Characterization of zinc oxide samples}

Figure 1 represents the X-ray diffraction spectra of the four samples of $\mathrm{ZnO}$, named (a) commercial zinc oxide, (b) zinc oxide prepared by hydrothermal method with a short aging time (sample I), (c) zinc oxide prepared by hydrothermal method with a long aging time (sample II), (d) zinc oxide prepared by direct precipitation method (sample III). The x-ray patterns for all charts are nearly identical in the values of $2 \theta$ except for the commercial sample which have some inconsiderable peaks. 

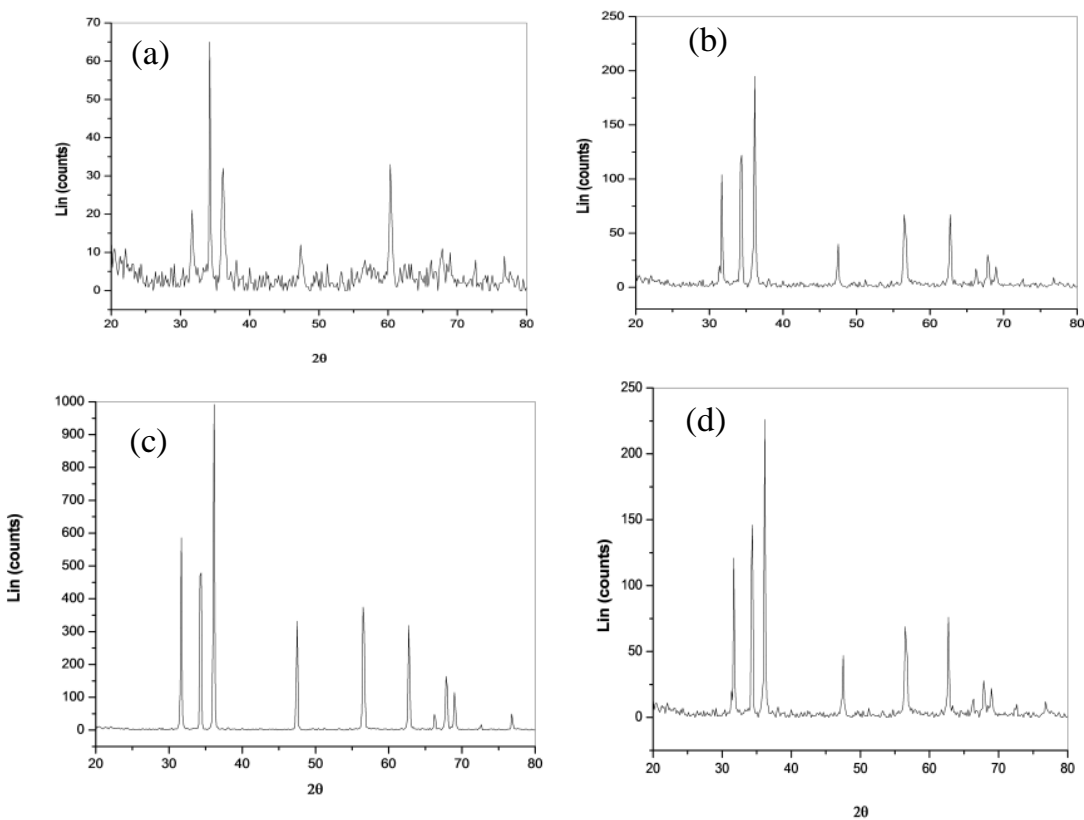

Fig. 1. X-ray diffraction patterns of (a) commercial $\mathrm{ZnO}$, (b) $\mathrm{ZnO}$ prepared by hydrothermal method with a short aging time, (c) $\mathrm{ZnO}$ prepared by hydrothermal method with a long aging time and(d) $\mathrm{ZnO}$ prepared by direct precipitation method.

The X-ray patterns indicate that the formation of hexagonal wurtzite phase of zinc oxide is in agreement with the results obtained by Mir et al. and Ghoul et al. ${ }^{(18}$, ${ }^{19)}$. Also, it is noticed that for all samples the peaks appear at $2 \Theta=31.8 ; 34.5 ; 36.3$; $47.7 ; 56.5 ; 62.7 ; 67.8$ and 69 with a negligible value. The appearance of these peaks can be attributed to (100), (002), (101), (102), (110), (103), (112), (201) plans of zinc oxide, respectively as pointed out by Peng et al. and Krithiga et al. ${ }^{(20,21)}$. Also, it is observed that sharpens of these peaks is well defined and narrow, showing that an asymmetry in the crystalline shapes was formed. The average particle size of the four samples was calculated using Scherer's Equation (22) (Table) 1:

$$
D=0.9 \lambda / B \cos \Theta_{B}
$$

where $D$ is the crystallite size, $\lambda$ the $\mathrm{x}$-ray wavelength (1.5418), $\Theta_{B}$ is the maximum of the bragg diffraction peak, and $B$ is the line width half maximum (in radians).

The results indicate that the three prepared samples have nano-particle size ranging from 18 to $37 \mathrm{~nm}$ while for the commercial sample the particle size is high (equal to $331 \mathrm{~nm}$ ) relatively to the prepared samples. The observed results are in a

Egypt. J. Chem. 57, No. 5,6 (2014) 
good agreement with the result obtained by El mir et al. ${ }^{(23)}$, Omri et al. ${ }^{(24)}$ and Amrut et al. ${ }^{(25)}$ and close to $\mathrm{ZnO}$ reported in JCPDS card (No. 36-1451).

TABLE 1. Particle size of the samples .

\begin{tabular}{|l|l|c|c|}
\hline No. & \multicolumn{1}{|c|}{ Sample prepared methods } & $\begin{array}{c}\text { Size estimated by } \\
\text { Scherer method }\end{array}$ & $\begin{array}{c}\text { Size estimated by } \\
\text { TEM } \\
\text { photography }\end{array}$ \\
\hline 1 & Commercial zinc oxide & 331 & $185-402$ \\
\hline 2 & $\begin{array}{l}\text { Method I (Hydrothermal with short } \\
\text { ageing and autoclaving time) }\end{array}$ & 37 & $26-52$ \\
\hline 3 & $\begin{array}{l}\text { Method II (Hydrothermal with long } \\
\text { ageing and autoclaving time) }\end{array}$ & 29 & $24-38$ \\
\hline 4 & Method III (Direct precipitation) & 18 & $8-27$ \\
\hline
\end{tabular}

Figure 2 represents TEM photograph of the prepared and the commercial samples. The commercial sample (a) shows a randomly shaped participates without defined structure. The particle size appeared to be from $185-402 \mathrm{~nm}$. For the sample prepared by the hydrothermal with short ageing and autoclaving time (b), the distribution of participates shows some coagulated particles and randomly distributed, while the other particles start to coagulate $(26-52 \mathrm{~nm})$. For the sample prepared by the hydrothermal with long ageing and autoclaving time (c) it is clearly observed, that some crystals plates start to be formed with defined edge. It is observed that most of plates take a defined hexagonal shapes but with non homogeneity in size 24-38 nm. For the sample prepared by direct precipitation method (d) an improvement in the crystallinty and well defined structure appears with size $(8-27 \mathrm{~nm})$.

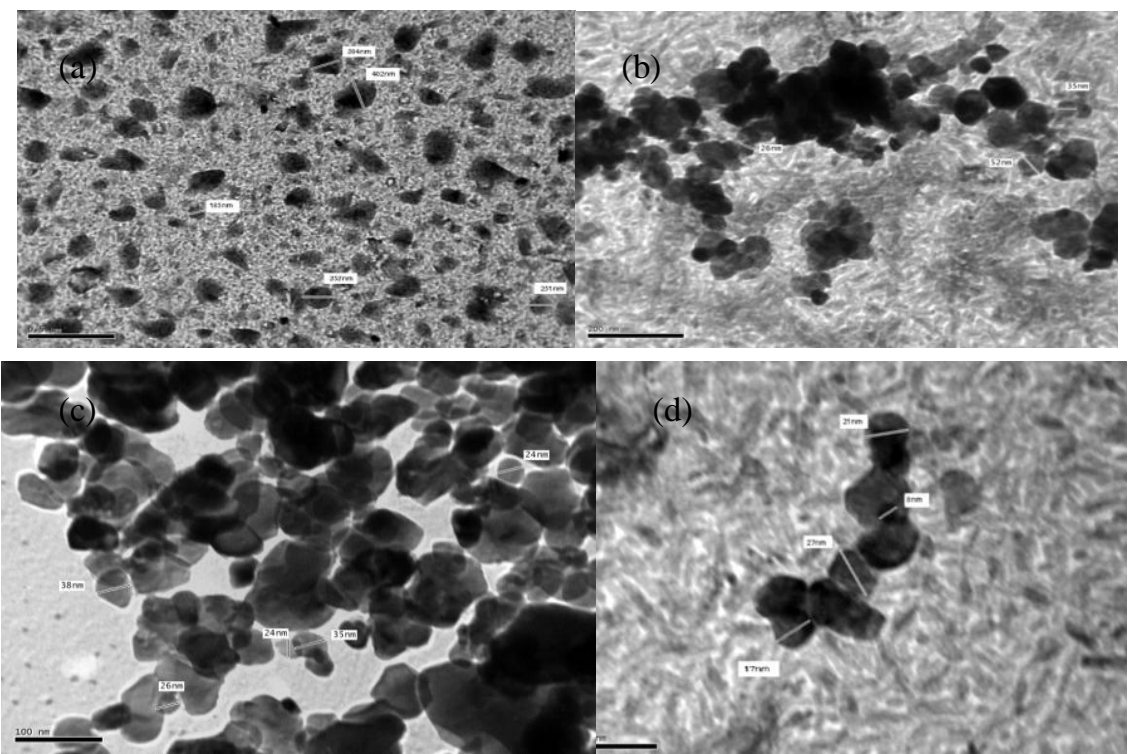

Fig. 2. TEM of (a) commercial $\mathrm{ZnO}(350 \mathrm{~nm})$, (b), (c) and (d) Nano $\mathrm{ZnO}(54 \mathrm{~nm}, 35$ $\mathrm{nm}$ and $20 \mathrm{~nm}$ ) 
Figure 3 represents the histogram of the particle size of the four samples under consideration.

Both the measurements of the particle size by scherer's equation or the TEM show that the prepared samples have nano-particle size.

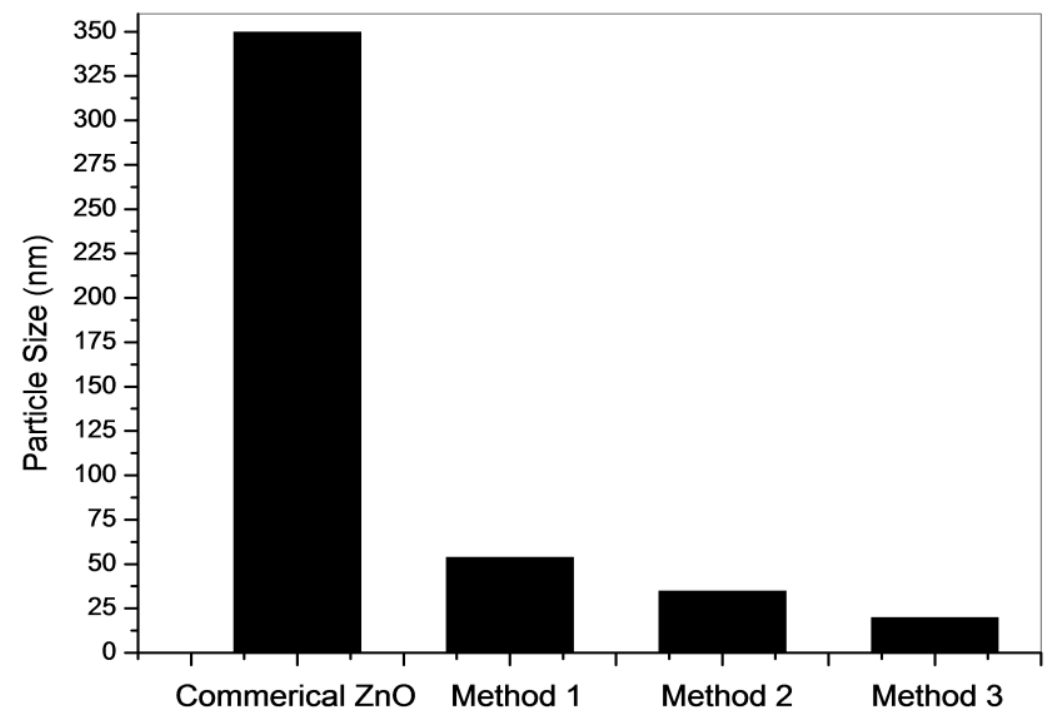

Fig. 3. The particle size using different prepared methods .

Results of the tested samples as pigments

Some measurements were carried out to evaluate the prepared $\mathrm{ZnO}$ as pigments in comparison with the commercial $\mathrm{ZnO}$. The specific gravity of all samples was shown in Fig. 4 a, from the curve it is clear that the commercial sample has higher specific gravity, while the sample (III) has lower specific gravity value. On the other hand, it is clear that specific gravity of all samples is ranging from 5.57 to 5.82 . These values indicate that all samples are suitable to be used as pigment, where no settling occurred.

The results of oil adsorption for all samples were shown in Fig. 4 b, the results also, indicate that the more suitable samples for using as pigment is sample (III) according to ASTM applied methods.

Egypt. J. Chem. 57, No. 5,6 (2014) 

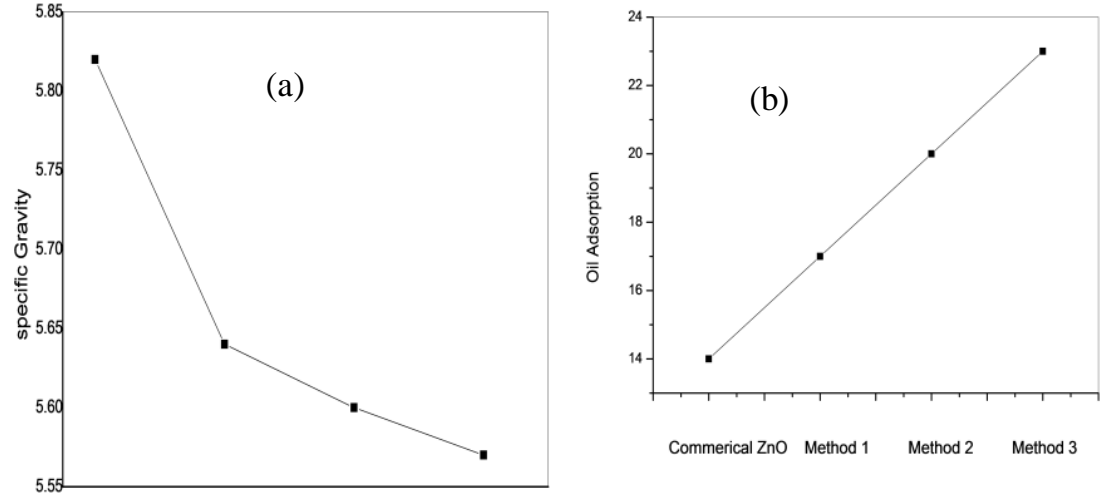

Commerical ZnO Method $1 \quad$ Method $2 \quad$ Method 3
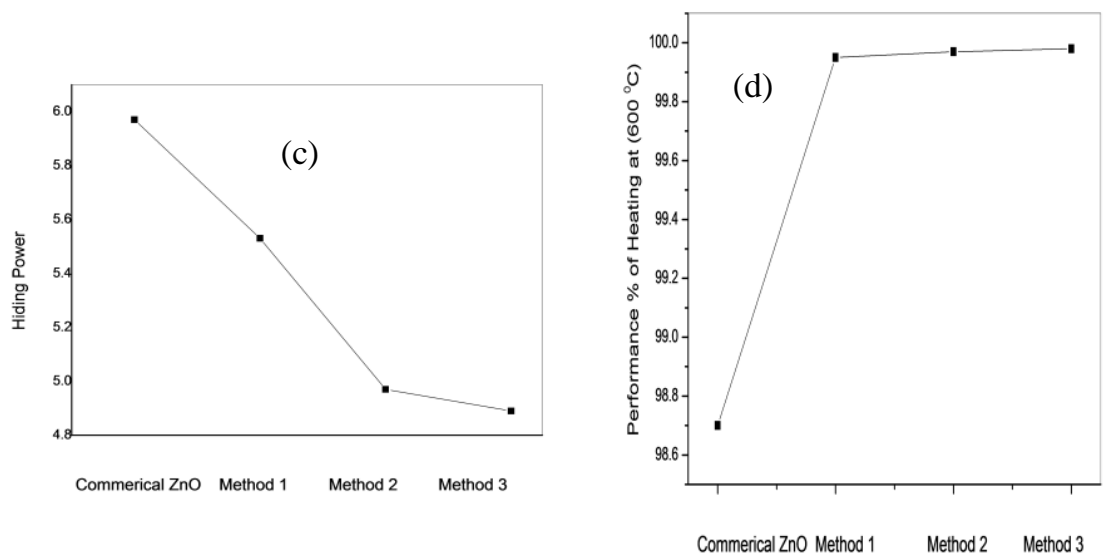

Fig. 4. Specific gravity, oil adsorption, hiding powerand heating at $600{ }^{0} \mathrm{C}$ tests for commercial $\mathrm{ZnO}$ and $\mathrm{Nano} \mathrm{ZnO}$ as a pigment.

Also, hiding power and heating performance of all samples were shown in Fig. $4 \mathrm{c}$ and empasise the same results.

In general, the agreement between measured values and those mentioned in the ASTM shows that as the particle size of the prepared samples decreases the efficiency of painting performances increases due to dispersion of $\mathrm{ZnO}$ through the substrate.

Also, the chemical resistance (acid and alkali resistances) was shown in Fig. 5 for all samples. The obtained results favored the use of $\mathrm{ZnO}$ nano oxides for paints with excellent results . 
A.A. Hanna et al.
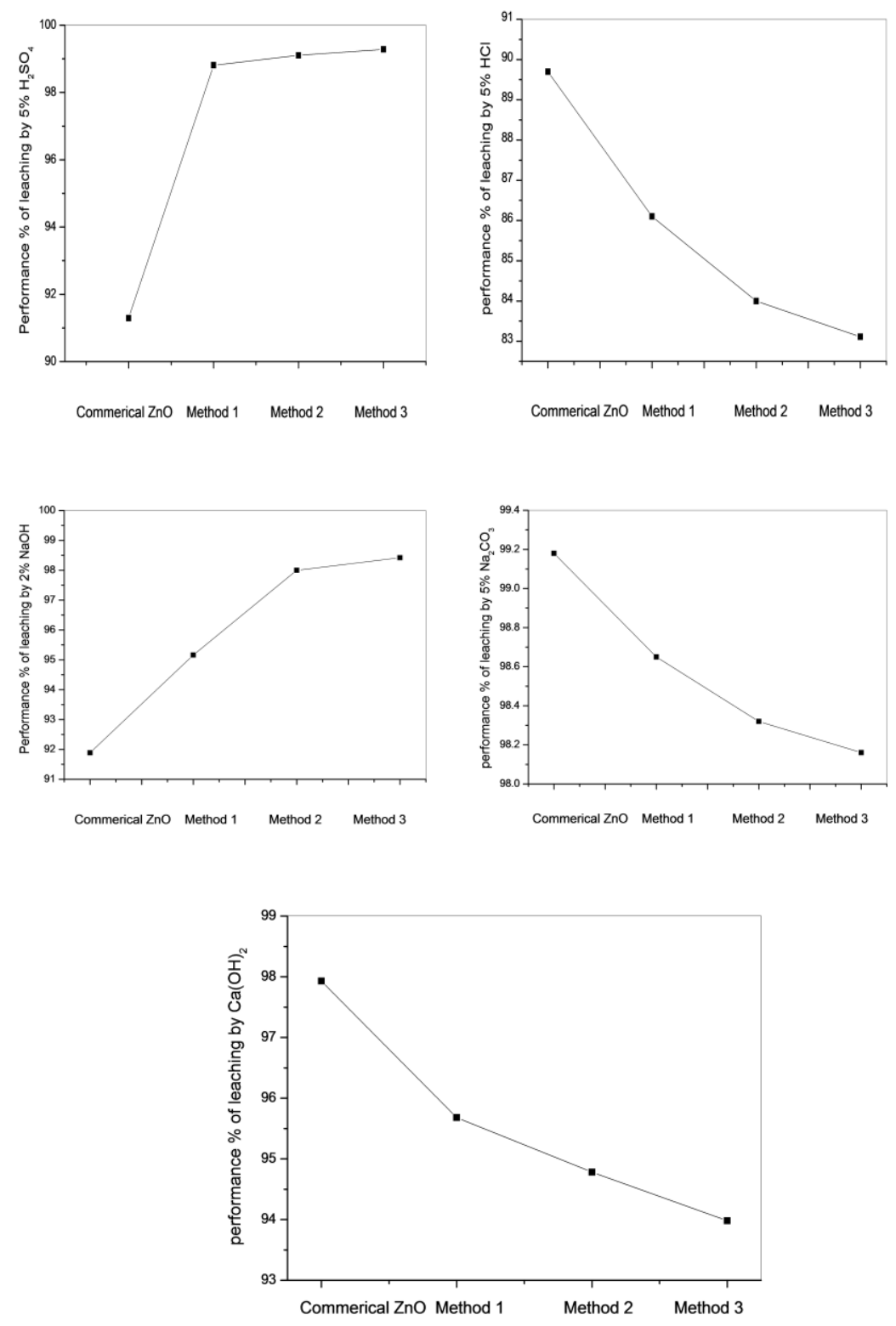

Fig. 5. Results of performance $\%$ of leaching by $5 \% \mathrm{H}_{2} \mathrm{SO}_{4}, 5 \% \mathrm{HCl}, 2 \% \mathrm{NaOH}, 5 \%$ $\mathrm{Na}_{2} \mathrm{CO}_{3}$ and $5 \% \mathrm{Ca}(\mathrm{OH})_{2}$ tests for commercial $\mathrm{ZnO}$ and nano $\mathrm{ZnO}$ as a pigment.

Egypt. J. Chem. 57, No. 5,6 (2014) 


\section{Conclusion}

From the analysis of the obtained data for the prepared samples of zinc oxides by hydrothermal and direct precipitation methods, it may be conclud that:

1- All prepared samples have nano-sized particle size.

2- The prepared samples can be used successflly as pigments, where they exhibit an excellent values according to ASTM .

3- As the particle size decreases the efficiency and the quality of paints increase, due to the disperssion of the small particale size of the pigment $(\mathrm{ZnO})$.

\section{References}

1. Chang Chun Chen, Synthesis and characterization of nano- sized $\mathrm{ZnO}$ powders by direct precipitation method. Chemical Engineering Journal, 144, 509-513 (2008).

2. Music, S., Influence of synthesis procedure on the formation and properties of zinc oxide. Journal of Alloys and Compounds, 347, 324-332 (2002).

3. Music, S., Precipitation of $\mathrm{ZnO}$ particles and their properties. Materials Letters, 59 2388-2393 (2005).

4. Vanathi, P., Rajiva, P., Narendhran, S., Sivaraj Rajeshwari, Pattanathu, K.S.M. Rahman and RajendranVenckatesh, Biosynthesis and characterization of phyto mediated zinc oxide nanoparticles: A green chemistry approach. Materials Letters, 134, 13-15 (2014)

5. Deng, Z., Chen, M., Gu, G. and Wu, L.M., A facile method to fabricate $\mathrm{ZnO}$ hollow spheres and their photocatalyticproperty. J. Phys Chem. B 112, 16-22 (2008)

6. Krishnakumar, T., Jayaprakash, R., Pinna, N., Singh, V.N., Mehta, B.R. and Phani, A.R., Microwave-assisted synthesis and characterization of tinoxide nanoparticles. Mater. Lett . 63, 242-5 (2008)

7. Cui, Y., Zhong, Z., Wang, D., Wang, W. U. and Lieber, C.M., High performance silicon nano wire field effect transistors, Nano Letters, 3, 149-152 (2003).

8. Lu, Y., Dajani, I.A. and Knize, R.J., ZnO nano rod arrays asp-n hetero junction ultra violet photo detectors. Electronics Letters, 42, 1309-1310 (2006).

9. Law, M., Greene, L., Jonhnson, J.C., Saykally, R. and Yang, P., Nano wire dyesensitized solar cells, Nature Materials, 4, 455-459 (2005).

10. Minami, T., Ida, S., Miyata, T. and Minamino, Y., Transparent conducting ZnO thin films deposited by vacuum arc plasma evaporation. Thin Solid Films, 445, 268 273 (2003).

11. Ellmer, K., Klein, A. and Rech, B., Transparent Conductive Zinc Oxide, Springer, New York (2008).

12. Amir Moezzi, Zinc oxide particles: Synthesis, properties and applications. Chemical Engineering Journal, 185-186, 1-22 (2012). 
13. Ristic, M. et al. Sol-gel synthesis and characterization of nanocrystalline $\mathrm{ZnO}$ powders. Journal of Alloys and Compounds, 397, L1-L4 (2005)

14. Chou, K.S., Chen, W.H. and Huang, C.S., ZnO nanorod arrays: Field-assisted growth in aqueous solution and field emission properties. J. Chin. Inst. Chem. Eng. 21, 327 (1990).

15. Singhal, M., Chhcbra, V., Kang, P. and Shah, D.O., Synthesis of zinc oxide/silica composite nanoparticles by flame spray pyrolysis. Mater. Res Bull. 32, 239 (1997).

16. Komarneni, S., Bruno, M. and Mariani, E., Synthesis of $\mathrm{ZnO}$ with and without microwaves. Mater. Res. Bull. 35, 1843 (2000).

17. Tsuchida, T. and Kitajima, S., Synthesis of zinc oxide nanocrystalline powders for cosmetic applications. Chem. Mater. 1, 78 (1989).

18. El Mir, L., Ben Ayadi, Z., Saadoun, M., Djessas, K., von Bardeleben, H.J. and Alaya, S., Magnetic properties of $\mathrm{ZnO}: \mathrm{Ni}$ aerogel nanopowders: Effect of thermal treatments, Boston, MA. J. Appl. Surf. Sci. 254, 570 (2007).

19. El Ghoul, J., Barthou, C., Saadoun, M. and El Mir, L., Sol-gel synthesis, structural and luminescence properties of MT-doped $\mathrm{SiO} 2 / \mathrm{Zn} 2 \mathrm{SiO} 4$ nanocomposites. J. Phys. B 405, 597 (2010).

20. Peng, W.Q., Qu, S.C., Cong, G.W. and Wang, Z.G., Evolution of $\mathrm{ZnO}$ nanostructures in sol-gel synthesis. Mater. Sci. Semicond. Process, 9, 156 (2006).

21. Krithiga, R. and Chandrasekaran, G., Synthesis, structural and optical properties of vanadium doped zinc oxide nanograins. J. Cryst. Growth, 311, 4610 (2009).

22. Cullity, B.D., Elements of X-Ray Diffraction, Addison-Wesley, Reading, MA,102 (1978).

23. El Mir, L., Amlouk, A., Barthou, C. and Alaya, S., Sol-gel synthesis, structural and luminescence properties of MT-doped $\mathrm{SiO}_{2} / \mathrm{Zn}_{2} \mathrm{SiO}_{4}$ Nanocomposites. J. Phys. B 388, 412 (2007).

24. Omri, K., Najeh, I., Dhahri, R., El Ghoul, J. and EI Mira, L., Effects of temperature on the optical and electrical properties of $\mathrm{ZnO}$ nanoparticles synthesized by sol-gel method. Microelectronic Engineering, 128,53-58 (2014).

25. Amrut S. Lanje, Satish J. Sharma, Raghumani S. Ningthoujam, Ahn, J.S. and Ramchandra B. Pode, Low temperature dielectric studies of zinc oxide $(\mathrm{ZnO})$ nanoparticles prepared by precipitation method. Advanced Powder Technology, 24, 331-335 (2013). 
تحضير و توصيف و تقييم اكاسيد الزنك النانومترى كمخضبات

عدلى عبالله حنا ، وليد عبد الحليم عبد الففار محمد و هلدى رفعت جلال

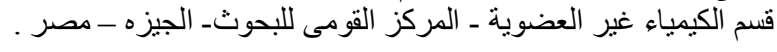

\begin{abstract}
تم تحضير ثلاث عينات من اوكسيد الزنك النانومثرى باستخدام الطريقة الحرارية

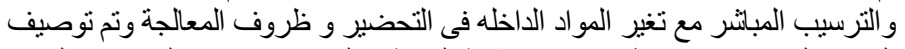

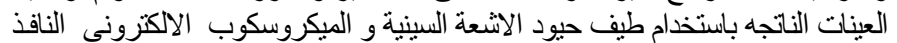

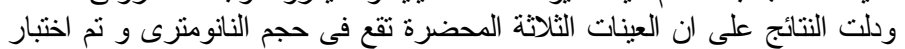

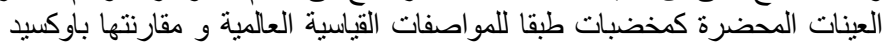
الزنك التجارى المستخدم فى الاسو اقدئ

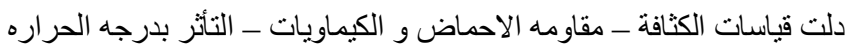

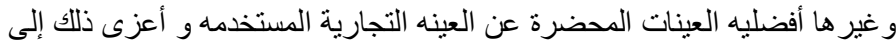
صغر حجم الحبييات مما يؤ هلها للانتثار.
\end{abstract}

